\title{
Gyermekkori zárt ujjsérülések sürgősségi vizsgálata nagyfelbontású ultrahanggal
}

\author{
DR. VARGA MARCELL', DR. TÓTH LUCA', DR. RIBES KITTI², \\ DR. PINTÉR SÁNDOR ${ }^{2}$
}

\section{ÖSSZEFOGLALÁS}

A kéz ujjainak zárt sérülései nagyon gyakoriak gyermekkorban. Az esetek döntő többségében célzott, kétirányú röntgenfelvétellel zárható ki, vagy erősíthető meg egy esetleges törés jelenléte. Magas frekvenciás ultrahang a röntgenhez hasonló hatékonyságú diagnosztikai értékkel bírhat. Közleményünkben a gyermekkori zárt ujjsérülések ultrahangos akut diagnosztikája során elért eredményeinket mutatjuk be. Vizsgálatainkat 14 év alatti gyermekeken végeztük, akik zárt, 1-3 napon belül elszenvedett kézujjsérülések miatt jelentkeztek ambulanciánkon. A vizsgálatokat $20 \mathrm{Mhz}$ frekvenciájú lineáris transzdúcerrel végeztük. 2017. október és 2018. április között 200 gyermek vizsgálatát végeztük el. Tévesen negatív szonográfiás leletet nem észleltünk. Tévesen pozitiv eredményt öt esetben találtunk. Az ultrahangvizsgálatok eredményét a röntgenvizsgálatokkal összevetve a csont corticalis eltérésre vonatkoztatott szenzitivitást 1-nek, a specifitást 0.96-nak, pozitiv prediktív értéket 0.92-nek, negatív prediktiv értéket 1-nek találtuk. A vizsgálók általi értékelés minimális különbséget mutatott. Az ultrahang rutin használata további értékes információkat adhat adott sérülés részletesebb diagnózisához. A zárt gyermekkori ujjsérülések diagnosztikájában a magas frekvenciás szonográfia „point of care” (betegágy melletti, sürgősségi) alkalmazása értékes kiegészítője lehet a napi diagnosztikának. A módszer rutin alkalmazása, illetve pontosan definiált szakmai és jogi hátterének megteremtése a jövő feladata.

\section{Kulcsszavak: $\quad$ Diagnosztika; Gyermekkor; Kézsérülés; Radiográfia; Sürgösségi betegellátás; Ujjsérülés; Ultrahang}

M. Varga, L. Tóth, K. Ribes, S. Pintér: Examinations with high frequency point of care sonography of pediatric closed finger injuries

Closed injuries of the fingers are very common in childhood. In the majority of cases, targeted twoplanes X-rays can exclude or confirm the diagnosis of possible fractures. High frequency ultrasound can have a diagnostic value similar to X-ray. In our report, we present the results of point of care sonography of pediatric finger injuries. In our study we included children under the age of 14 with closed, 1-3 days old finger injuries. The examinations were carried out with a $20 \mathrm{MHz}$ frequency linear transducer. Between 2017 and 2018 we evaluated 200 children. We did not detect any false negative sonographic result. We found five false positive sonographic cases. Regarding bony cortex disruptions we found the following results of ultrasound tests compared to X-ray examinations: sensitivity 1 , specificity 0.96 , positive predictive value 0.92 , and negative predictive value 1 . Point of care high frequency sonography can be a valuable addition in the diagnostics of pediatric finger injuries. The routine use and the accurately defined professional and legal background of the method are still the tasks of the future.

Keywords:

Child; Emergency service, hospital; Finger injuries - Diagnostic imaging; Point-of-Care Systems; Radiography; Ultrasonography - Methods 


\section{BEVEZETÉS}

A kéz ujjainak zárt sérülései nagyon gyakoriak gyermekkorban. Az Országos Traumatológiai Intézet Gyermektraumatológiai Ambulanciáján évente mintegy 1500 akut kézujjsérülés kerül ellátásra. Az esetek döntő többségében - például zúzódások, elmozdulás nélküli epiphyseolysisek, palmaris lemez sérülések, diaphysealis infrakciók - konzervatív kezelés elegendő, míg kisebb hányadukban - csontos extensor ín abruptiók, diszlokált ízületi törések - mútéti beavatkozás is szükséges lehet (2).

Az ujjsérülések sikeres diagnosztikájához a fizikális státusz gondos feltérképezésén túl, általában valamilyen képalkotó vizsgálat is szükséges $(2,9)$. Bár tapasztalt kézsebész általában már a fizikális vizsgálat alapján is ki tudja zárni a súlyosabb (operatív igényű) sérüléseket, a járóbeteg ambulanciákon a beteget először vizsgáló ellátó orvos általában nem tekinthet el az objektív értékelést is lehetővé tevő képalkotás elvégzésétől. A gyermekkori ujjsérülések ellátása során ez általában az érintett végtag célzott kétirányú röntgen- felvételét (AP + oldal) jelenti (1, 2, 9). Gyermekkori röntgenfelvételek elrendelésénél mindig figyelembe kell venni a nemzetközileg általánosan elfogadott ALARA (as low as reasonably achievable) irányelvet mely kimondja, hogy a kívánt diagnosztikai eredményt az ésszerúen elérhető legalacsonyabb sugárterheléssel kell megszerezni, ha az más, nem sugaras eljárással nem váltható ki. Bár egy ujjra centrált standard kétirányú felvétel csekély sugárterhelést jelent, az esetleges nem típusos beállítások, a gyermek kooperációjának hiánya, több ujj egyidejű sérülése esetén további felvételekre is szükség lehet (1).

Közleményünkben a gyerekkori zárt ujjsérülések ultrahangos akut diagnosztikája során elért eredményeinket mutatjuk be.

\section{ANYAG ÉS MÓDSZER}

Vizsgálatainkat olyan 14 év alatti gyermekeken végeztük, akik zárt, 1-3 napon belül elszenvedett kézujjsérülések miatt jelentkeztek ambulanciánkon. A már zárt epifízisekkel rendelkező, illetve a kéz egyéb régiójának sérülését is elszenvedő gyermekeket a vizsgálatba nem vontuk bele. Szintén kizártuk azokat a betegeket, akik nem traumás eredetű kézujj panaszok miatt jelentkeztek.

Közvetlenül a fizikális vizsgálatot követően, valamennyi gyermeknél magas frekvenciás ultrahang képalkotás történt. A vizsgálatot Zonare ZS3 típusú készülékkel, 20 Mhz frekvenciás lineáris transzdúcerekkel végezte alapvető ultrahangos képzettséggel rendelkező ortopéd -traumatológus szakorvos illetve ortopéd traumatológus rezidens.

A vizsgálatokat standard longitudinális síkokból (palmaris, dorsalis, ferde radiális és ferde ulnaris) végeztük, az így nyert szonográfiás képeket értékeltük, rögzítettük és elmentettük (1-2. ábra).

A vizsgálatok elvégzéséhez Intézetünk Szakmai Igazgatósága beleegyezését adta. A szülőket a vizsgálatok előtt tájékoztattuk, és beleegyezésüket kértük. Valamennyi esetben sor került az ellenoldal összehasonlító vizsgálatára is.

A szonográfiás értékelés során három fó szempontot vettünk figyelembe:

1. Észlelhető eltérés a csont corticalisok kontúrján?

2. Észlelhető egyéb lágyrész eltérés, patológia?

3. Észlelhető-e lágyrész árnyék kiszélesedés a palmaris csont corticalis és a flexor inak közt a DIP és PIP ízületek magasságában?

A vizsgáló klinikus ezt követően rögzítette az ultrahang és a fizikális vizsgálat alapján véleményezett diagnózisát. Pozitívnak értékelt ultrahang kép esetén az elváltozás elhelyezkedéséről, konfigurációjáról alkotott vélemény is rögzítésre került. Az ultrahang vizsgálatokat követően célzott kétirányú röntgenfelvételeket végeztünk.

Az ultrahangkép alapján a klinikus illetve a röntgenkép alapján a radiológus által felállított diagnózisok egyezését vizsgáltuk, ez alapján számoltunk specificitást, szenzitivitást, pozitív és negatív prediktív értéket.

A két orvos értékelte a nem saját maga által készített szonográfiás képeket is a hozzátartozó röntgen ismerete nélkül. Az vizsgálók közti egyetértést a Cohen-féle kappa érték kalkulációjával értékeltük. 


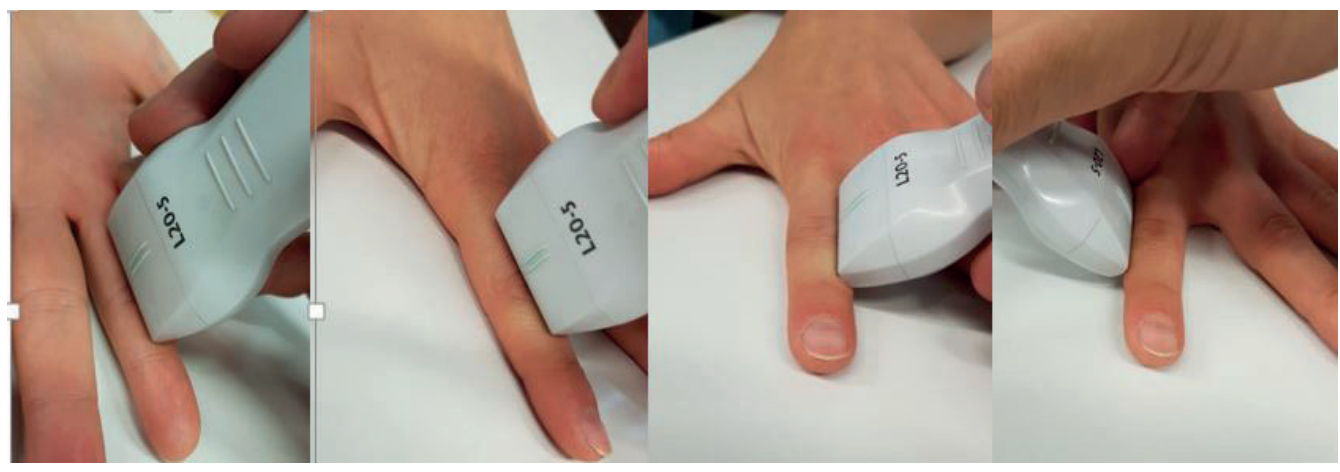

1. ábra

Standard vizsgálati sikok - transzdúcer tartás

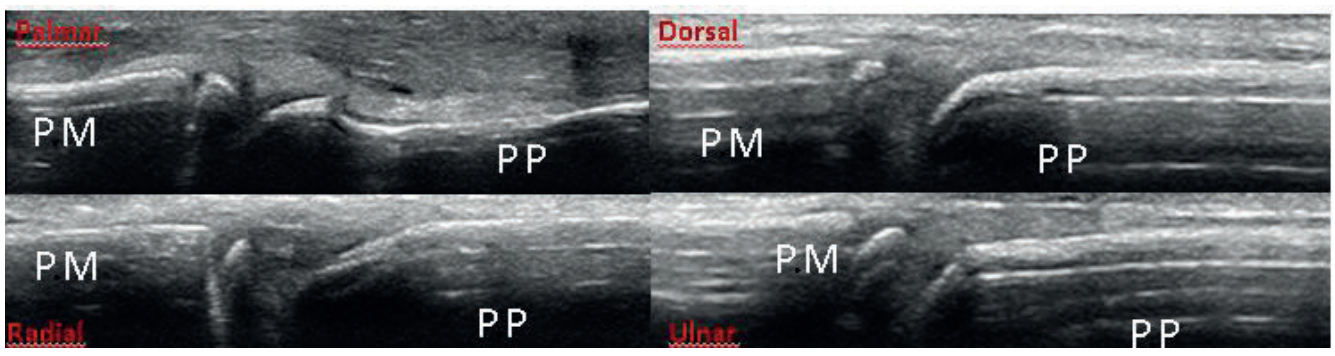

2. ábra

Standard sikok ultrahang képe

PP: phalanx proximalis, PM: phalanx media

\section{EREDMÉNYEK}

2017. október és 2018. április között 200 gyermek vizsgálatát végeztük el a fentiek szerint. A sérülések megoszlása a következő volt: 139 esetben (69.5\%) csont eltérés nem igazolódott. A röntgenfelvételen primeren 61 (30.5\%) esetben észleltünk csonteltéréssel járó elváltozást, ezek a következő megoszlást mutatták: 20 (10\%) alapperc avulsio, 6 (3\%) végperc avulsio, 7 (3.5\%) epiphyseolysis, 5 (2.5\%) diaphysis törés, $21(9 \%)$ torus törés, 2 (1\%) végperc ízületbe hatoló törés. Öt esetben járt a képalkotás komolyabb klinikai konzekvenciával, amikor mútéti ellátásra is szükség volt (3 végperc avulsiónál, és a két ízületi törésnél).

A primer UH kép 66 esetben mutatott csonteltérést. Így összesen öt, elsődlegesen ál-pozitívnak minősített eredményt észleltünk. Tévesen negatív szonográfiás leletet nem észleltünk. A vizsgálatok csont corticalis eltérésre vonatkoztatott szenzitivitását így 1-nek, a specificitást 0.96-nak, pozitív prediktív értéket 0.92-nek, negatív prediktív értéket 1-nek találtuk.

A röntgennel és ultrahanggal is negativ csont corticalis leletek mellett ugyanakkor 110 esetben (55\%) különböző mértékben kiszélesedett szonográfiás lágyrészárnyékot (0.09-0,34mm) találtunk a PIP, illetve DIP ízület magasságában.

Egy esetben mellékleletként ínhüvely gangliont találtunk. A két vizsgáló általi értékelés minimális különbséget mutatott. Egyezési \%: 95.08, Cohen-féle kappa érték: 0.88. Ez utóbbi érték meghatározását a GraphPad szoftver QuickCals nevű alkalmazásával végeztük el. Eredményeinket az I-II. táblázat foglalja össze. 
I. táblázat A sérüléstípusok megoszlása, illetve az ultrahang és röntgen eredményeinek összehasonlítása

\begin{tabular}{|c|c|c|c|}
\hline Ujjsérülés n=200 & Röntgen & $\begin{array}{c}\text { Ultrahang } \\
\text { Pozitiv }\end{array}$ & Ultrahang negatív \\
\hline $\begin{array}{c}\text { Zúzódás, ízületi } \\
\text { distorsio }\end{array}$ & 139 & 5 & 134 \\
\hline $\begin{array}{c}\text { Alapperc avulsiós } \\
\text { törés }\end{array}$ & 20 & 20 & 0 \\
\hline $\begin{array}{c}\text { Végperc avulsiós törés } \\
\text { Epiphiseolysis }\end{array}$ & 6 & 6 & 0 \\
\hline Ízületi törés & 7 & 7 & 0 \\
\hline Phalanx diaphysis & 2 & 2 & 0 \\
\hline törés & 5 & 5 & 0 \\
\hline Alapperc torus törés & 21 & 21 & 0 \\
\hline
\end{tabular}

II. táblázat Az ultrahangdiagnosztika hatékonyságának értékelése

\begin{tabular}{|c|c|}
\hline Szenzitivitás & 1 \\
\hline Specificitás & 0.96 \\
\hline Negatív prediktív érték & 1 \\
\hline Pozitív prediktív érték & 0.92 \\
\hline Vizsgálók közti egyezés, & $95.08 \%$ \\
\hline Cohen-féle kappa érték & 0.88 \\
\hline
\end{tabular}

\section{MEGBESZÉLÉS}

Az ultrahang nagy elönye, hogy non-invazív, sugárterheléssel nem jár, és korlátlanul ismételhető. Magas frekvenciáljú szonográfiával az ujj lágy részei igen részletgazdagon képezhetőek le $(3,6,7)$. Ez további nagy előny a hagyományos röntgen képalkotással szemben, ahol a diagnosztika leginkább a csontos struktúrák ábrázolására korlátozódik, a lágyrészek állapotáról csak minimális információkat nyerhetünk $(3,6,7)$.

$\mathrm{Az}$ elmúlt években több tanulmány is megjelent az ujjak különféle kórfolyamatainak eredményes szonográfiájáról (3). Az ultrahang rutinszerūn többnyire non-accidentális patológiás folyamatok (pattanó ujj, lágyrész tumorok, arthritisek korai előrejelzése) diagnosztikájában használatos, akut ujj törésdiagnosztikáról egyelőre csak minimális irodalom található $(4,5,8)$.
Vizsgálatunk során arra kerestük a választ, hogy a gyermekambulancián nagyon gyakran előforduló ujjsérülések hagyományos röntgendiagnosztikájának van-e alternativája. Eredményeink alapján a következő következtetésekre jutottunk:

1. A negatív eredményekkel járó szonográfiás felvételek esetén a röntgen képalkotás elviekben elhagyható lenne. Bár anyagunkban álnegatív eredményt nem találtunk, tekintettel arra,hogy a konzervatív terápia zúzódások és a legtöbb csontsérülés esetén hasonló (1-3 hetes rögzítés sínben, gyógytorna), ultrahangvizsgálattal nem felismert elmozdulás nélküli törésnek, epiphyseolysisnek lényeges klinikai konzekvenciája nincs.

2. A pozitív szonográfiával járó esetek több mint 70\%-ban a törés pontos konfigurációja is megállapítható volt.

Ezek többnyire az alappercek bázisát érintő avulsiós, illetve a csontkontúr megtöretést 
okozó torus törések voltak (3. ábra). Ezeknél a betegeknél szintén mérlegelni lehetne a röntgendiagnosztika igénybevételének szükségét. A diszlokált epiphyseolysisek, rotációval járó diaphysis törések esetén ugyanakkor a törés pontosabb konfigurációját már nem lehetett kizárólag szonográfia alapján meghatározni, így ezekben az esetekben a röntgenfelvételek semmiképpen nem nélkülözhetőek.

3. Az ultrahang rutin használata további értékes információkat adhat, adott sérülés finomabb diagnózisához. A negatív röntgenfelvételekkel járó esetekben a lágyrész árnyék különböző mértékű kiszélesedését észleltük, mely az ízületi bevérzés nagyságára utalhat (4. ábra).

Feltételezzük, hogy a kiszélesedés mértéke jelezheti a sérülés súlyosságát, így az alkalmazott immobilizálási idő is egyénre szabható lenne. Ezt később további vizsgálatokkal szeretnénk igazolni. Anyagunkban egy esetben észleltünk ínhüvely gangliont mellékleletként, mely utal annak jelentőségére, hogy további non-accidentális patológiák is felismerésre kerülhetnek.

4. Elképzelhetőnek tartjuk, hogy bizonyos esetekben az ultrahang szenzitívebb lehet a röntgennél. Vizsgálataink során primeren öt ál- pozitív esetet észleltünk, amikor a pozitívnak minősített ultrahangkép ellenére a primer röntgen negatív volt. Három esetben ugyanakkor az elhúzódó fájdalom miatt egy héttel később készült ismételt, más beállítású röntgenfelvétel már igazolta a kis corticalis megtörést, így ezekben az esetekben inkább primeren röntgennel nem igazolható okkult törésekről volt szó (5. ábra).

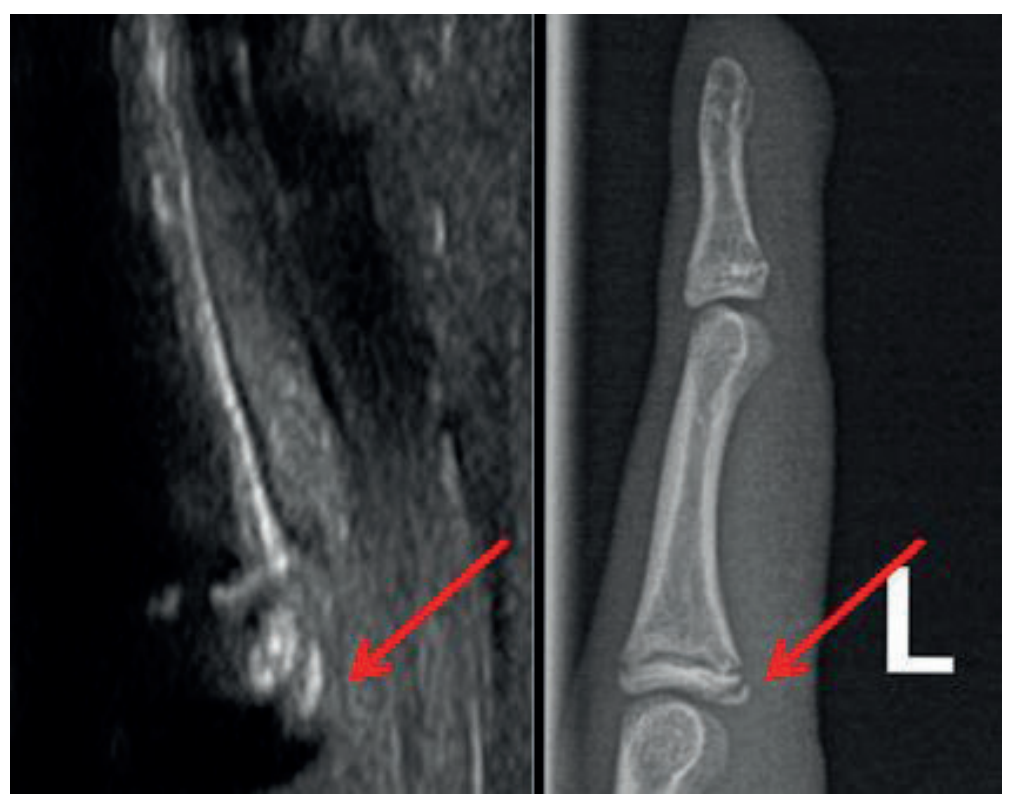

3. ábra

Alapperc avulsiós sérülésének (piros nyil) ultrahang-és röntgenképe 


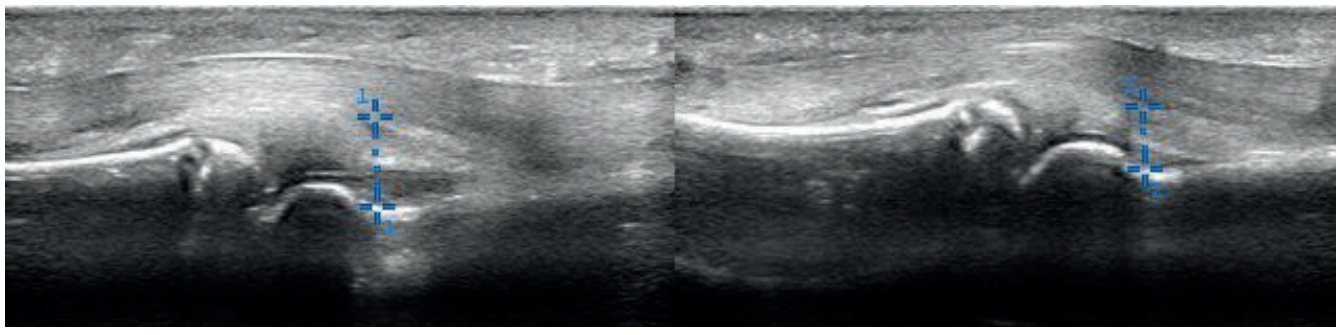

4. ábra

PIP ízület ventralis longitudinális síkból végzett összehasonlító vizsgálata. Az érintett oldalon (bal kép) a flexor inak alatt a lágyrész árnyék $0.11 \mathrm{~mm}$-el szélesebb illetve kis folyadékgyülem is látható, mely a palmaris lemez részleges sérülésére utal

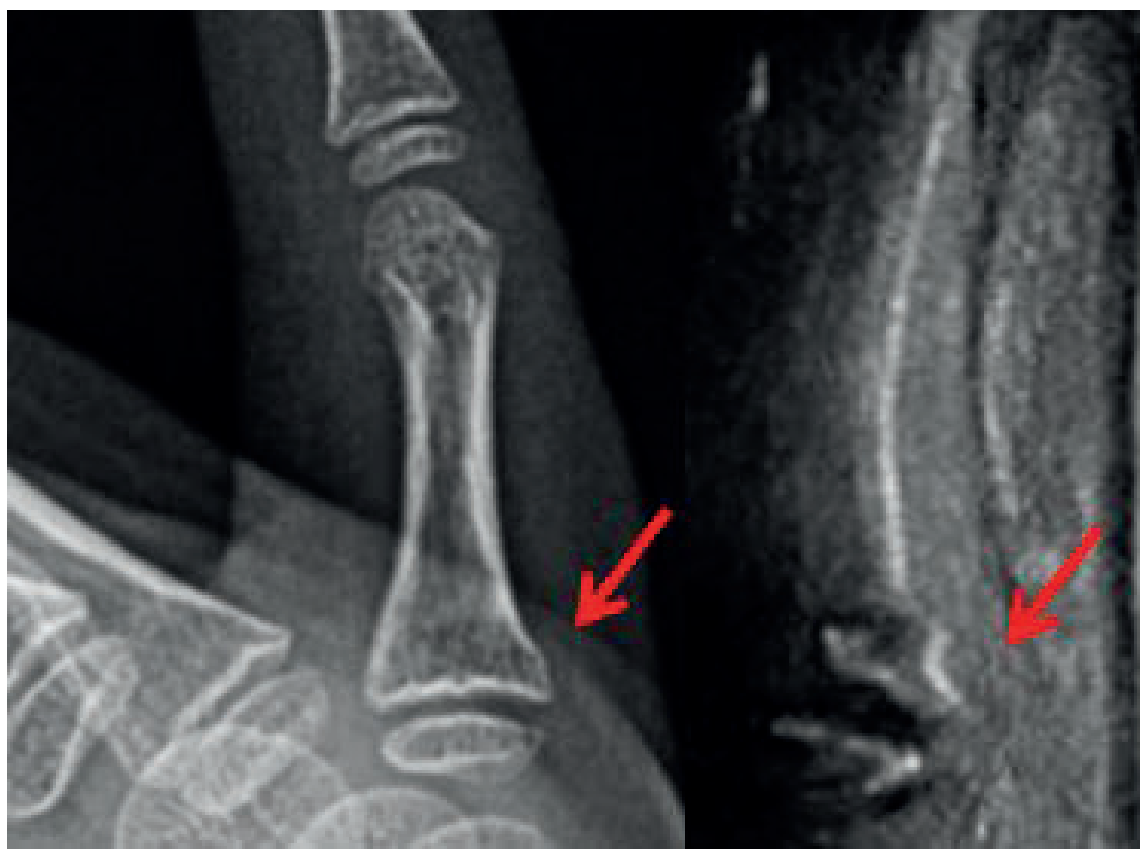

\section{5. ábra}

Alapperc torus törése

(a radiológus által negatívnak minősített röntgen ellenére az ultrahang felvételen egyértelmü corticalis megszakadás látható). Utólag elemezve a képet a primer röntgenfelvételen is sejthető a törés (piros nyilak)

\section{KÖVETKEZTETÉSEK}

A zárt gyermekkori ujjsérülések diagnosztikájában a magas frekvenciás szonográfia „point of care" alkalmazása értékes kiegészítője lehet a napi diagnosztikának. A röntgenfelvételek rutin rendelése helyett segíthet a felesleges vizsgálatkérések redukciójában, és jelentősen gyorsíthatja az ellátási folyamatot. A fenti módszer rutin alkalmazása, illetve pontosan definiált szakmai és jogi hátterének megteremtése még a jövő feladata. 


\section{IRODALOM}

1. Abzug J. M., Dua K., Bauer A. S., Cornwall R., Wyrick T. O.: Pediatric phalanx fractures. J. Am. Acad. Orthop. Surg. 2016.24. (11): e174-e183. https://doi.org/10.5435/jaaos-d-16-00199

2. Abzug J. M., Mehlman C. T.: The community orthopaedic surgeon taking trauma call: Pediatric phalangeal fracture pearls and pitfalls. J. Orthop Trauma, 2017. 31. Suppl. 6: S1-S5. https://doi.org/10.1097/bot.0000000000001013

3. Aksay E., Kilic T. Y., Yesılaras M., Tur F. C., Sever M., Kalenderer O.: Accuracy of bedside ultrasonography for the diagnosis of finger fractures Am. J. Emerg. Med. 2016. 34: 809-812. https://doi.org/10.1016/j.ajem.2016.01.010

4. Blaivas M., Lyon M., Brannam L., Duggal S., Sierzenski P.: Water bath evaluation technique for emergency ultrasound of painful superficial structures. Am. J. Emerg. Med. 2004. 22. (7): 589-593. https://doi.org/10.1016/j.ajem.2004.09.009

5. Gitto S., Draghi A. G., Draghi F.: sonography of non-neoplastic disorders of the hand and wrist tendons. J. Ultrasound Med. 2018. 37. (1): 51-68. https://doi.org/10.1002/jum.14313

6. Lee S. A., Kim B. H., Kim S. J., Kim J. N., Park S. Y., Choi K.: Current status of ultrasonography of the finger. Ultrasonography, 2016. 35: 110-123. https://doi.org/10.14366/usg.15051

7. Tayal VS, Antoniazzi J, Pariyadath M, Norton HJ.: Prospective use of ultrasound imaging to detect bony hand injuries in adults. J. Ultrasound Med. 2007. 26. (9): 1143-1148. https://doi.org/10.7863/jum.2007.26.9.1143

8. Wang T., Qi H., Teng J., Wang Z., Zhao B.: The role of high frequency ultrasonography in diagnosis of acute closed mallet finger injury. Sci. Rep. 2017. 7. (1): 11049 https://doi.org/10.1038/s41598-017-10959-x

9. Wieschhoff G. G., Sheehan S. E., Wortman J. R., Dyer G. S., Sodickson A. D., Patel K. I., Khurana B.: Traumatic finger injuries: what the orthopedic surgeon wants to know. Radiographics, 2016. 36. (4): 1106-1128. https://doi.org/10.1148/rg.2016150216

\section{Dr. Varga Marcell}

Péterfy Kórház-Rendelőintézet és

Manninger Jenő Országos Traumatológiai Intézet

1081 Budapest, Fiumei út 17. 